\title{
Application of theoretical and methodological components of nursing care ${ }^{\dagger}$
}

ISSN 1794-9831

E-ISSN 2322-7028

Vol. 13 No. 2

Jul - Dic 2016

Cúcuta, Colombia

Received:

March 22nd of

2016

Alba Cecilia Pardo-Vásquez ${ }^{* * *}$
Approved:

June 10th of 2016

Introduction: the theoretical and methodological components are the proper expertise in nursing, and it refers to models, theories, care process, taxonomy of nursing diagnoses, system of nursing intervention classification, and system of outcomes classification, which base nursing care into professional practice. Methodology: research was performed on Google Scholar, reviewing the databases of Scielo, Ciberindex, Index Enfermería, Dialnet, Redalyc, Medline, identifying 70 published articles between 2005-2015, and selecting 52 of them. The keywords used were: nurse care, nursing diagnostic, classification, nursing theory, in spanish and portuguese. Results: training students, receive knowledge in the nursing process, NANDA International, classification of the interventions, nurse results and theoretical components. The Dorothea Orem, Callista Roy, Nola Pender, Virginia Henderson, Florence Nightingale, and Betty Neuman theories are applied. The application of the nursing process is limited and low familiarity with the international taxonomy by nurse professionals in the assistance area is noticed. Conclusions: the challenge of nursing is to continue to solidify the scientific knowledge and to undo the gap between theory and practice.

KEY WORDS: nursing care, nursing diagnosis, classification, nursing theory ${ }^{* * * *}$.

To reference this article / Para citar este artículo / Para citar este artigo

Morales-Aguilar RS, Lastre-Amell GE, Pardo-Vásquez AC. Application of theoretical and methodological components of nursing care. Rev. cienc. cuidad. 2016; 13(2): 107-120.

$\dagger$ This paper derives from the current research project entitled: Theories and conceptual models applied by nurses of a health institution from the district of Barranquilla.

\footnotetext{
* Nurse, MSc in Nursing. Professor. Universidad Metropolitana. Barranquilla, Colombia. Email: rosa.morales@ unimetro.edu.co

** Nurse, MSc in Public Health. Professor. Universidad Metropolitana. Barranquilla, Colombia. Email: glastreamell@yahoo. es

*** Nurse, MSc in Education. Professor. Universidad Metropolitana Barranquilla, Colombia. Email: albacpardo@yahoo.es **** Descriptors of the Health Sciences (DeCS), in the site http://decs.bvs.br/E/ homepagee.htm from the Virtual Library of Health from the project BIREME, World Health Organization and the Pan American Health Organization.
} 


\section{Aplicación de los elementos teóricos y metodológicos del cuidado de enfermería}

\section{RESUMEN}

Introducción: los elementos teóricos y metodológicos son conocimientos propios de enfermería y se refieren a modelos, teorías, proceso de atención, taxonomía de diagnósticos de enfermería, el sistema de clasificación de intervenciones de enfermería, y el sistema de clasificación de resultados, los cuales fundamentan el cuidado de enfermería en la práctica profesional. Metodología: se realizó búsqueda en Google Chrome, revisando las bases de datos de Scielo, Ciberindex, Index Enfermería, Dialnet, Redalyc y Medline, identificando 70 artículos publicados entre 2005-2015, seleccionándose 52. Las palabras clave utilizadas fueron: cuidado de enfermería, diagnóstico de enfermería, clasificación, teoría de enfermería, , en idiomas español y portugués. Resultados: los estudiantes en formación reciben conocimientos en el proceso de enfermería, NANDA Internacional, clasificación de las intervenciones, resultados enfermeros y elementos teóricos. Las teóricas aplicadas fueron Dorotea Orem, Callista Roy, Nola Pender, Virginia Henderson, Florence Nigthingale y Betty Neuman. La aplicación del proceso de enfermería es limitada y hay escasa familiaridad con la taxonomía internacional por parte de los profesionales de enfermería en el área asistencial. Conclusiones: el reto de enfermería es continuar dando solidez al cuerpo de conocimiento científico y deshacer la brecha entre la teoría y la práctica.

PALABRAS CLAVE: cuidado de enfermería, diagnóstico de enfermería, clasificación, teoría de enfermería. 


\section{Aplicação de elementos teóricos e metodológicos dos cuidados de enfermagem}

ISSN 1794-9831

E-ISSN 2322-7028

Vol. 13 No. 2

Jul - Dic 2016

Cúcuta, Colombia

\section{RESUMO}

Introdução: os elementos teóricos e metodológicos são os conhecimentos próprios em enfermagem, e se referem a modelos, teorias, processos de atendimento, taxonomia de diagnósticos de enfermagem, o sistema de classificação de intervenções de enfermagem, e o sistema de classificação de resultados, os quais fundamentam os cuidados de enfermagem na prática professional. Materiais e métodos: realizou-se busca em Google Acadêmico, revisando as bases de dados de Scielo, Ciberindex, Index Enfermagem, Dialnet, Redalyc, Medline, identificando 70 artigos publicados entre 2005-2015, selecionando-se 52. As palavras-chave utilizadas foram cuidados de enfermagem, diagnóstico de enfermagem, classificação, teoria de enfermagem, processo de atendimento, intervenção e resultados de enfermagem, nas línguas espanhol e português. Resultados: os estudantes em formação, recebem conhecimentos no processo de enfermagem, NANDA Internacional, classificação das intervenções, resultados enfermeiros e elementos teóricos. Se aplicam as teorias de Dorotea Orem, Callista Roy, Nola Pender, Virginia Henderson, Florence Nigthingale e Betty Neuman. A aplicação do processo de enfermagem é limitado e é percebida falta de familiaridade com a taxonomia internacional, principalmente pelos professionais de enfermagem na área assistencial. Conclusão: o desafio da enfermagem é de continuar a solidificar ao corpo de conhecimento científico e desfazer a lacuna entre a teoria e prática.

PALAVRAS-CHAVE: cuidados de enfermagem, diagnóstico de enfermagem, classificação, teoria de enfermagem. 
E-ISSN 2322-7028

Vol. 13 No. 2

Jul - Dic 2016

Cúcuta, Colombia

\section{INTRODUCTION}

The theoretical and methodological components of care, represent a combination of nursing skills such as models, theories, nursing care process (PAE), taxonomy, diagnosis of the North American Nursing Diagnosis Association (NANDA), the system of nursing intervention classification (NIC), and system of outcomes classification (NOC), that guide the professional practice; these are part of the theoretical foundation and knowledge that support the professional exercise, meaning it represents the foundation necessary to implement nursing care in practice (1).

The nursing essence, according to the American Nurses Association (ANA) is characterized by the protection, promotion and optimization of health and capacities, the relief of suffering through the diagnosis and treatment of human responses and promote the care of individuals, families, communities and populations (2).

According to Bros and Serra (3), nursing is usually defined as a science that has a body of knowledge, which is acquired by observation, theory, and practice based on scientific evidence; likewise, it is considered and art and a philosophy. Besides, nursing is directly related to theory/practice.

As a discipline represents the body of knowledge related with the study of the care of human health that involves both the science and art of nursing. It is science, because it is based on a theoretical framework and an art because it requires the skills and abilities to provide care (2).

In this sense, to provide nursing care, tools are used to give an answer to the problems in practice, such as healthcare and life, in other words, the application of theoretical and methodological components, underlying their professional work (4).

In the decade of the 50's, the theoretical nursing knowledge about the care was initiated with postulates of Madeleine Leninger, who argued that care is a necessity for humans, and the essence of nursing is care. In the same way, she considered that care is to achieve health, well-being and the conversation of cultures and civilization. In addition to Leninger, other theorists have contributed to the evolution of nursing (5).
Caring and taking care of, constitute the nurse labor, as "a procedure, a way, a manner, a style, a pattern, a dimension, a system, a structure, a process, or others, with formal and informal attitudes and strategies, visible, felt, perceived or not, that set the practice of be-doing through the human health in their process of living" (5).

According to Puga et al. (6), the nursing care to an individual, family, and community either healthy and/ or sick are object of studies of the profession and, in order to satisfy the human necessities, it is taken as an application basis of PAE.

The application of the theoretical and methodological components of nursing care supports the daily practice through the description, explanation, prediction, and control of the phenomenon. According to Ramalho et al., (7) the application of the nursing theories in the practice, education, research and administration in the different dimensions of attention, provides tools to the nurses in the areas where they work.

Within the theoretical components there are models and theories in nursing that according to Marriner and Raile (8) are classified as: evolution of nursing theories, philosophies, nursing models, nursing theories, intermediate theories and future of the nursing theory. Its evolution evolution led to a nursing knowledge, by which nursing practice is based in scientific knowledge. This goal served the profession throughout the twentieth century and the present XXI century.

As methodological components exist: the process of nursing care (PAE), a taxonomy of nursing diagnosis (NANDA), the nursing intervention classification system (NIC), and the nursing outcomes classification (NOC), considered work tools (9).

Delgado (9), points that when this methodology, is taken to practice, it presents difficulties both for students and professionals, for reasons such as lack of time to apply it, the interaction between the theory and practice is not clear, and there are few group study spaces for professors, it leads this methodology to not be able to reach its full function. As for the process of nursing care (PAE), this one provides mechanisms that allow the application of knowledge to the professional as well as abilities to diagnose and treat the patient response to potential or real health problems (10). 
In the same way, Aguilar (11) manifests that during the professional training, understanding about the nurse care process is given, allowing professionals to become thoughtful and analytical in their professional work, performing actions with scientific basis dependently, independently and interdependently, therefore strengthening the profession.

However, Huitzi et al., (12) mention that the ability to incorporate changes regarding the nursing process is increasing. If the delays in Gipuzkoa (Basque Country) are analyzed and compared with America in the application of the nursing methodology, it is observed that the time required to incorporate changes is decreasing: the process of nursing is introduced twenty years later than suggested in America, the nurse diagnosis comes fifteen years later, and the terminologies NIC-NOC are just six years later.

This proves that the advanced knowledge in nursing in developed countries, compared to developing countries, takes time to assimilate, but also it is observed, that this gap is smaller as it happens in Colombia because of the advances in science and technology.

On the other hand, aspects related with the standardization of the categories-diagnosis (NANDA taxonomy), its ability and indicators facilitate the practice application of nursing care (13).

According to Gallardo (10), nursing is a discipline in constant evolution, and the necessity to grow the knowledge to support its practice has created a variety of theories and conceptual models to orientate the critical thinking in this field professionals; however, there are still difficulties in its use, as these models and theories, are not reflected in the practice that constitutes the real nursing world. Also, the nursing taxonomy and its classification are relatively recent and there is a lack of familiarity with these models and theories with them by the professionals that perform assistance work.

A study made in Mexico (1) about the experiences of the students on the nursing process in the hospital field, revealed that the application of the nursing process was limited, which reduces the possibility for students to use this scientific tool as a work method to bring nurse care during their professional training and in their future professional life.
The study made by Cogollo (14) in Monteria, Colombia, allowed to demonstrate abilities and skills for the care of an individual, family, and groups, applying the nursing care process, the model of attention for family health and the Dorothea Orem general theory.

In another study (2) related to the theoretical components of the nursing care in the intensive care unit (ICU), the researchers consider that strategies should be established promptly to make possible an approach from the academy to the reality of nurse care and vice versa; being the only possible way to take the theory into practice.

Also, Gutierrez (15), mentions that only three nurses out of ten apply PAE to bring care to the patients. The researchers recommend to develop studies about this topic and strengthen the training about PAE for both nurses in service and undergraduate students, assuming responsibilities from NANDA, NIC, NOC (NNN).

The study also admits that the students have realized the advantages of having a common language to give priority and plan the care needed, acquiring a greater autonomy and certainty when making clinical judgements.

\section{METHODOLOGY}

This is a literature article review, about the application of theoretical and methodological components in nurse care. The literature review was based in the documental analysis of theories, conceptual and methodological nurse models and its practical application. For this, a series of stages were followed: establish the topic objectives and determine the selection criteria, research of articles that met the criteria, tabulate the characteristics of each article, identify the methodological quality, collect as much articles as possible and analyze the results, and lastly elaborated a structured report of the research.

Thus, using search engines in Google Scholar; the Scielo, Ciberindex, Index Enfermería, Dialnet, Redalyc, and Medline databases were reviewed. The research was done between the months of September and November of 2015. The number of articles in the databases, on average, were between 1 and 70 
E-ISSN 2322-7028

Vol. 13 No. 2

Jul - Dic 2016

Cúcuta, Colombia search records after the combination of the different keywords. Also, the research was limited over a period of time of ten years between 2005 and 2015, and the languages Spanish and Portuguese. The consulted databases generated a total of 70 articles, from which, 51 achieved the inclusion criteria.

For the literature review the health descriptors used for the research of information were taken into account: nursing care, nursing diagnosis, classification, and nursing theory

Followed this process, articles were selected classifying them and distinguishing them in: scientific articles originated from research, review (44), legal regulations (2), book (1), thesis (1), and clinical cases (3) of opinion, in which the main objective was the application of the theoretical and methodological components in nurse care, also the collection of articles that made reference to the application of nurse care and the standardized language of the NANDA, NIC and NOC taxonomy.

\section{Application of theories and models in practice}

According to the literature review about the topic two opinion articles were identified: According to Duran (16), the new tendencies in the nursing theoretical development must be understood from its own context. The development and advancement of this science have made the application of the theory in practice difficult, the latter making it the axis of this discipline.

In addition, Gallardo (10), indicates that nursing is considered a discipline of evolution, framed for its questioning referring to its object of study. The necessity to amplify the knowledge to support its practice has created the development of various theories and conceptual models in order to orientate the critical thinking of the nurse professionals; however, there still exist difficulties in its use.

On the other hand, when a documental review was made, research articles and thesis abstracts were identified, where the scope of learning abilities of a nursing student in clinical practice was evident, related with the application of the nursing care process and the standardized language of NANDA, NIC and NOC; finding that education is actually received about these previously mentioned aspects.
Also, they are considered as methodological tools, analysis framework and referencing to decisionmaking, which allow helping the students to have a greater commitment and responsibility with the patient care (17-19).

Another important aspect found in the review of the nursing care theoretical components in the ICU, according to Gallego et al., (2), it was evidenced that the nurses responses: "Nursing theories and models are not used and are not considered essential for its professional practice". Another expression indicates: "I have been fifteen years performing my profession without knowing nursing theories and models" Some nurses expressed: "These are not practical and bring many complications", but agree that its necessary to "Have conceptual clarity to be able to bring care" (2).

These findings are alarming due to the neglecting of use of the theory components for nurse care, however, the nursing curriculum has been taught at university levels. It's worth mentioning, that in Colombia, the Colombian Association of Nursing Colleges (ACOFAEN), has been working in the guidelines of the education of this topic in the country.

As for the articles referring to the models and theories of nursing it was found that: Navarro and Castro (20), confirm that the theory contribute to the theoretical foundation of nursing, orientates the nursing care, and the process of nursing constitutes the tool that allows give this care through a systematic and rational method. López and Guerrero (21), meanwhile, demonstrate the importance of theory in the nursing knowledge development and indicate its great utility for research and the practice in this field.

Rodriguez (22), mentions that the theory would notably contribute to the nursing development, that nursing is not only created as an instrument for the care of the patient, but it has a wide vision of nursing that makes the path to excellence on the care of the patient. Furthermore, it proposes that the care that is brought to the patients can be optimized if some of the nursing models are applied.

Prado et al. (23), explain that the theory offers, the nurse professionals, tools to bring quality care related with the binomial health-illness, and as well as they consider that it should be accepted for the development and strengthening of the Cuban nursery. 
According to Moreno y Alvarado (24), in the world theories and models in practice have been applied, as in Mexico and Colombia, demonstrating that the change in an adaptive mode affects the other modes and some incentives influence in the process of adaptation of individuals; Trejos (25), explained that the main concepts of health of Nola Pender were put into practice, and the intervention in its study gave as result, changes in lifestyle on the case studied. Pino (26) affirms that the use of the Henderson theory when incorporating all the stages of the nursing process, would allow the professionals to implement advanced care in the nursing service of the pediatrician.

Regarding the history and philosophy of science in the Bernardes study et al., (27), where the environment theory was applied, in an elder with bronchial asthma, in his home, some alterations of the environment were detected and identified by Florence Nightingale, as elements with incidence in the health of the individual. The authors concluded that education must be given for the health in the home of the patient.

The Backes et al. study (28), emphasizes the role and the social enterprising spirit in the education, from the nursing theories, meaning developing a knowledge able to integrate the different traditions for the development of practices. Durán (16), explains that the new tendencies in the theoretical development of nursing should be understood from its own context.
Analyzing these articles, the researchers consider that the models and theories that are most used are the previously mentioned. This means that the unlimited human scope, social, psychological and scientific that characterizes nursing suggests that for its development is essential to have a philosophical, conceptual and theoretical basis, to facilitate the implementation of nursing models and theories in all areas (27).

In this regard, the experience of Moreno is emphasized (29), about the importance of the Conceptual Models and theories of nursing describing that "for education purposes is essential that the nursing programs have a clear reference framework, in order to facilitate the orientation and the development in the subjects that are in the curriculum.

Rodrigues et al. (30) as a result of the clinical case studied, indicate that the use of the Neuman theory of conception associated with the prevention of bedsores, applying the Braden Scale as a clinical model, its efficient in decreasing bedsore occurrences in the intensive care unit. Is considered that the theory of Betty Neuman defines a model of total person for nursing, a holistic concept of the care given to the patient, being a qualified as a model for the nursing practice.

Table 1 shows, a summary of the article review, about the practical application of theories and models.
ISSN 1794-9831

E-ISSN 2322-7028

Vol. 13 No. 2

Jul - Dic 2016

Cúcuta, Colombia 
Table 1. Article review about the application of theories and models in practice.

\begin{tabular}{|c|c|c|}
\hline Theories and Models & Title in English & Authors \\
\hline Theory of Dorothea Orem & $\begin{array}{l}\text { Model of Dorothea Orem applied to a community } \\
\text { group through the nursing process }\end{array}$ & Navarro and Castro(20) \\
\hline General Theory of Orem & $\begin{array}{l}\text { International perspective relative to Orem General } \\
\text { Theory }\end{array}$ & López and Guerrero (21) \\
\hline $\begin{array}{l}\text { Theory of Nursing integrated to the care and } \\
\text { self-care, Virginia Henderson }\end{array}$ & $\begin{array}{l}\text { Nursing models integrated patient care nephrology in } \\
\text { the Cuban context }\end{array}$ & Rodríguez (22) \\
\hline $\begin{array}{l}\text { Theory of deficiency of self care: Dorothea } \\
\text { Orem }\end{array}$ & $\begin{array}{l}\text { The theory Deficit of selfcare: Dorothea Orem, starting- } \\
\text { point for quality in health care }\end{array}$ & Prado et al.,(23) \\
\hline $\begin{array}{l}\text { Application of the model of Adaptation of } \\
\text { Callista Roy }\end{array}$ & $\begin{array}{l}\text { Application of Callista Roy's Adaptation Model in } \\
\text { Latin America: a Review of the Literature }\end{array}$ & Moreno and Alvarado (24) \\
\hline Nola Pender Model & $\begin{array}{l}\text { Aplication of health promotion model from Nola Pend- } \\
\text { er in a sedentary teenager }\end{array}$ & Trejos (25) \\
\hline Henderson theory & $\begin{array}{l}\text { Henderson's theory and its application in advanced } \\
\text { nursing care in a pediatric ward }\end{array}$ & Pino (26) \\
\hline Florence Nightingale Theory & $\begin{array}{l}\text { Application of Florence Nightingale's theory to an old } \\
\text { patient suffering from bronchial asthma }\end{array}$ & Bernardes (27) \\
\hline $\begin{array}{l}\text { Innovative theoretical-practical experience in } \\
\text { the teaching of disease. }\end{array}$ & $\begin{array}{l}\text { Theoretical and practical experience with an innovative } \\
\text { approach to nursing education }\end{array}$ & Backes et al. (28) \\
\hline Theory & $\begin{array}{l}\text { Theory, support of the nursing science and practice: } \\
\text { trends }\end{array}$ & Durán (16) \\
\hline Conceptual models and nursing theories & $\begin{array}{l}\text { Importancia de los modelos conceptuales y teorías de } \\
\text { enfermería: Experiencia de la Facultad de Enfermería } \\
\text { de la Universidad de la Sabana }\end{array}$ & Moreno (29) \\
\hline Betty Neuman Theory & $\begin{array}{l}\text { Theoretical conceptions of neuman associated with } \\
\text { prevention of pressure ulcers: An experience report }\end{array}$ & Rodrigues et al. (30) \\
\hline
\end{tabular}

Source: own elaboration.

\section{Application of the nursing process}

Regarding the application of the nursing care process, the bibliographic review provided the following results: Gutiérrez (15), whom indicates that shortage of time during the shift, activity of administration of medicine, and having more than four years in professional labor, are determining factors for the non-implementation of PAE, and knowing how to implement it is a determining factor for its application.

Ledesma and Rino (31), consider, in their analysis, that the nursing care process allowed the elaboration of a central category of processes such as actions of routine care; another finding in the article points out the significance that nurses attribute, to their day-today work, the process of nursing care used in their job, which is different to what is taught and learned in school. The authors compare the experience of the school -where the process is done step by step, with few patients, and there individual situations and selected situations; with the workplace, with the workplace, where activities are routine, diverse and PAE lose continuity in professional work. This analysis is based on expressions like: "It is very different from what we learn in school, I am talking about 20 years ago when I finished my studies, over the years, you start losing this continuity, we start leaving behind things that are important" (31).

For Rojas and Pastor (32), the professionals are young women with low experience, which take care of the patient making a medical evaluation, perform planning based on the medical diagnosis, and follow the established protocols in the ICU. These nurses declare not using PAE -although; the nurses evaluate,

† This title has English version. 
plan and intervene, and on a lesser extent, the nurses, formulate diagnosis and evaluate-, and have a low level of clinical skills.

Duque confirms (33) that PAE is of vital importance for all the nursing professionals. However, for the institution, the work overload and the multiple assignments to the professional affect the disciplinary responsibilities; although the willingness to bring quality care exists.

Correa and García (34), whose case study was made under the conceptual framework of the adaptation model of Roy, and through the nursing process, as a methodological tool to prioritize care, confirm that the obtained results are considered satisfactory, since the level of adaptation of a newborn was improved in the physiological mode.

This is proved in the study of García and Ibáñez (35) where the nursing care process is pointed out as important, given that it contributes to the established in the Law 1438 of 2011 (36), with relation to the identification of risks on an individual, familial and communal level, besides facilitates providing health services, education, prevention, treatment, and rehabilitation.

Tirado et al. (37), argue that the nursing process and the standardized languages are work tools that have made possible a considerable increase in the publishing of clinical cases in scientific journals. On that basis, the author proposes a set of suggestions that would contribute to the writing labor and establish a determined structure that works as a guideline in clinical cases to manage cares based on nursing taxonomies.

In relation to the taxonomies used by NANDA, NIC, y NOC, in the study of Navarrete and Santiago (38), the experience of applying PAE in a person with pemphigus vulgaris is showed, which allowed to perform the discipline with a methodological rigour, generating positive results in the treated patient; likewise, the information-communication from the interdisciplinary team improved, the family got involved in the acquaintance and well-being of the patient, also the patient attended the appointments on time.

Aguilar et al. (11), researched the knowledge levels of the nursing process and its efficacy in its application, and confirming that the knowledge levels exhibited by nurses in the hospitalization and critical areas are enough, obtaining an average of 6.7 in a scale from 1 to 10 . Regarding the self-efficacy, $50 \%$ of the nurses in the hospitalization area are completely sure they are able to do it, while $55.1 \%$ of nurses in critical areas are only sure they are able to do it. The authors suggest the need to strengthen the learning skills and mechanisms of self-efficacy in the nursing process, expecting to reinforce the professional care for the health of individuals.

Table 2 contains articles about the application of nursing care process.
ISSN 1794-9831

E-ISSN 2322-7028

Vol. 13 No. 2

Jul - Dic 2016

Cúcuta, Colombia 
Table 2. Review of articles about the application of the nursing care process.

\begin{tabular}{|l|l|}
\hline \multicolumn{1}{|c|}{ Title in English } & \multicolumn{1}{c|}{ Authors } \\
\hline $\begin{array}{l}\text { Factors that determine the application of nursing processes in hospitals in } \\
\text { Villavicencio, Colombia, 2008 }\end{array}$ & Gutiérrez (15) \\
\hline $\begin{array}{l}\text { The nursing process presented as routine care actions: building its } \\
\text { meaning in clinical nurses' perspective }\end{array}$ & Ledesma and Mendes (31) \\
\hline Intensive care unit nursing care process application & Rojas and Pastor (32) \\
\hline $\begin{array}{l}\text { Factors related to the applicability of the Nursing Process in a health } \\
\text { institution of high complexity in Medellin, Colombia }\end{array}$ & Duque (33) \\
\hline $\begin{array}{l}\text { Roy's adaptation model based nursing process on the attention to the } \\
\text { newborn with hyperbilirubinemia }\end{array}$ & Correa and García (34) \\
\hline Systematization of a care experience with adolescents & García and Ibáñez (35) \\
\hline $\begin{array}{l}\text { How to write clinical case studies in nursing using the NANDA, NOC, } \\
\text { NIC taxonomies }\end{array}$ & Tirado et al. (37) \\
\hline $\begin{array}{l}\text { Implementation of a plan of care using the model of Virginia Henderson } \\
\text { (fourteen needs), to a person who presents lesions caused by pemphigus } \\
\text { vulgaris }\end{array}$ & Navarrete and Santiago (38) \\
\hline $\begin{array}{l}\text { Nivel de conocimientos acerca del proceso enfermero y la percepción de } \\
\text { autoeficacia para su aplicación }\end{array}$ & Aguilar et al. (11) \\
\hline
\end{tabular}

Source: own elaboration.

\section{Review of articles about the taxonomy application of NANDA, NOC and NIC}

Regarding the taxonomy application of NANDA, NOC and NIC, the literature review provided the following results: Cobos (39) explains that the usage of a nursing language (NNN), is a similar methodology to the nursing application process, and could have an effect in the improvement of the healthcare quality. For Oreja and Alegre (40) the correlation of the three languages provides criteria the professionals to choose the more adequate results and interventions for the patients, in relation with the nursing diagnosis.

Regarding the study of Escaño and Rebola (41), the authors state that the developments of an individualized care plan, which collected the nursing interventions, based on the NNN taxonomy, downplayed the effect of sequels and improved the quality of life of the patient, with beneficial results.

Bros (42), mentions that in the teaching-learning process, the new organization of the subject, based in the criteria set by the European University Association (EUA) and the usage of the three standardized nursing languages, has allowed students the acquisition of tools that stimulate the critical and reflexive reasoning, and for teachers, an opportunity to modernize and make the existing structure flexible, developing a more open and creative spirit.

In turn, González and Moreno (43), on the application of the theory of self-care deficit and the stages of the nursing process, indicate that the linkage of this theory with the NNN taxonomy facilitates the education of the nursing process for students in the clinical practice. Similarly, Tirado et al. (37), propose a series of guidelines that contribute to a unified structure in the publishing of a clinical case, based in the use of the NNN taxonomy, contemplating all the phases of the nursing process.

The study of García and Rivas (44), with respect to the percentage of survivals in polytraumatized patients, describes the relation of NANDA labels and NOC indicators: 21 out of the 26 NANDA diagnosed labels were found within more than $50 \%$ of the studied population and, from this, six were found in the total number of cases, becoming constants for the elaboration of diagnostics.

According to Rivas et al. (45) the obtained results in the study of patients with diagnostics of cervical cancer, which identified nursing diagnostic labels, considered that the standardization of a professional language for the generation of care guides could be implemented as 
protocols of attention linked to the NANDA, NOC and NIC taxonomies, as a disciplinary methodological source to guarantee the quality and security of the patient.

Therefore, it can be inferred that the application of the NNN taxonomy contributes to strengthen the quality of nursing care, regarding a standardized language that guides processes and nursing procedures. Regarding the teachinglearning process, it provides tools that develop the critical and reflexive thinking in the student trainees.

The applicability of nursing diagnostics should be emphasized for the current situation of Colombia, as its evidenced in the study of Pinilla and Pérez (46), who affirm that the school children victims of the social and domestic violence by displacement, present diagnostics with major prevalence such as: willingness to improve the self-concept, willingness to improve communication, fear and risk of posttraumatic stress disorder (PTSD), the less prevalence as: ineffective confrontation, and risk of violence directed to others.

The above-mentioned nursing diagnostics deserve a meticulous evaluation and proper handling, otherwise, if not intervened, it could become a population with high risk of mental disorders.

Meanwhile, the study of Aguilera et al. (47), revealed the importance of standardizing the language and nursing care, using as a working methodology the nursing process and the NNN taxonomy linkage, which is significant for decision making in the nursing practice at the healthcare level.
Hein and De Abreu (48), research in clinical, surgical and critical patients, aimed to explore in deep the knowledge about NOC and classify nursing results to evaluate the implemented nursing interventions from a group of specific patients, based on nursing diagnostics (DE) that show up more frequently.

In that study (48), the risk of infection is the most frequent of the three studied nursing services. From the 21 results proposed by the NOC for the DE, eight were validated by experts $(38.1 \%)$ and, the DE deficit of self-care-bathroomhygiene was the second in order of frequency.

Borre et al. (49), emphasizes the importance of teaching the methodological and theoretical application of nursing care in schools of higher education, stating that the academic communities of nursing must prepare new generations, to be agents of transformation, dealing with challenges and trends in health care and disease in the world. Sancho and Prieto (50), explain that currently, nursing is immerse in an innovative and complex process of conceptualization of the discipline.

Today, in the nursing university curriculums it is observed that all these theoretical components, the PAE tool and the use of the taxonomies are articulated in the learning process of nursing students, as a good training methodological tool for the care of the patient, in an autonomous and responsible manner; therefore, the students have comprehended the advantages of an unique language (13). In table 3, the articles about the application of the NANDA, NOC, and NIC taxonomy are observed.
ISSN 1794-9831

E-ISSN 2322-7028

Vol. 13 No. 2

Jul - Dic 2016

Cúcuta, Colombia 
Table 3. Review of articles about the application of the NANDA, NOC, and NIC taxonomy.

\begin{tabular}{|l|l|}
\hline \multicolumn{1}{|c|}{ Title of the article } & \multicolumn{1}{|c|}{ Authors } \\
\hline $\begin{array}{l}\text { Impacto, de la implementación de una metodología normalizada y un } \\
\text { sistema de registro de información de cuidados de enfermería, en la } \\
\text { calidad asistencial }\end{array}$ & Cobos (39) \\
\hline $\begin{array}{l}\text { Interrelaciones NANDA, NOC, NIC. Metodología Enfermera. A } \\
\text { propósito de un caso }\end{array}$ & Oreja and Alegre (40) \\
\hline $\begin{array}{l}\text { Taxonomía diagnóstica NANDA, NOC, NIC en paciente con Colangitis } \\
\text { Aguda que sufre Pancreatitis tras CPRE }\end{array}$ & Escaño and Rebola (41) \\
\hline $\begin{array}{l}\text { Application of the NANDA, NOC and NIC standardised languages to a } \\
\text { Geriatric Nursing undergraduate course }\end{array}$ & Bros (42) \\
\hline $\begin{array}{l}\text { Factors that determine the application of the nursing process in healthcare } \\
\text { institutions in Villavicencio Colombia. }\end{array}$ & Gutiérrez ( 15) \\
\hline $\begin{array}{l}\text { Tools for teaching nurses in clinical teaching with the focus on Nanda- } \\
\text { Nic-Noc }\end{array}$ & González and Moreno (43) \\
\hline $\begin{array}{l}\text { Relation of NANDA labels and NOC indicators, in respect to survival } \\
\text { rates in polytraumatized patients }\end{array}$ & García and Rivas (44) \\
\hline $\begin{array}{l}\text { Diagnostic labeling in hospitalized patients with diagnosis uterine } \\
\text { cervical cancer }\end{array}$ & Rivas et al. (45) \\
\hline $\begin{array}{l}\text { Prevalence of nursing diagnoses in school displaced } \\
\text { victims of social and intra-family violence }\end{array}$ & Pinilla and Pérez (46) \\
\hline $\begin{array}{l}\text { Methodological proposal for developing a clinical guide of care: } \\
\text { hemodialytic treatment }\end{array}$ & Aguilera et al. (47) \\
\hline $\begin{array}{l}\text { Nursing Outcomes Content Validation According to Nursing Outcomes } \\
\text { Classification (NOC) for Clinical, Surgical and Critical Patients }\end{array}$ & Hein and De Abreu (48) \\
\hline
\end{tabular}

Source: own elaboration.

\section{CONCLUSIONS}

From the perspective of the review made about the application of the theoretical and methodological components of nursing care, a common element, that now is emphasized is that one of the biggest challenges in nursing currently is to keep providing a solid body of scientific knowledge. The nursing profession has evolved in the last 20 years, on the experience of application of models and theories, which has contributed to connect the theory and the practice.

It is convenient, to remark that the application of the theoretical and methodological components of nurse care is crucial in the discipline for the linkage between theory and practice, suggesting to the nursing academic and professional units to keep incorporating the disciplinary knowledge into practice and similarly, exploring new strategies as the nursing based on scientific evidence.

Nursing is characterized as having a great humanistic, social, psychological and scientific scope. Therefore, it is necessary, to continue strengthening the discipline, with research about the application of theoretical and methodological components about nursing care, since the application is restricted by its complexity and difficult understanding from the personnel working in the healthcare institutions.

\section{CONFLICT OF INTEREST}

The authors declare not having any conflict of interest. 


\section{BIBLIOGRAPHIC REFERENCES}

1. Pecina-Leyva RM. Experiencias de los alumnos sobre la aplicación del proceso enfermero en el área hospitalaria. Rev. Enf Neurol 2012; 11(1): 21-24.

2. Gallego M, Leal M, Ramos X. Elementos teóricos del cuidado de enfermería en UCI. Repertorio de Medicina y Cirugía 2009; 18(2): 76-81.

3. Bros-Serra M. Aplicación de los lenguajes estandarizados NANDA, NOC y NIC en la asignatura de Enfermería Geriátrica. Rev. Gerokomos. 2006; 17(3): 140-143.

4. República de Colombia. Ministerio de Educación Nacional. Ley 911 de 2004, octubre 6, por la cual se dictan disposiciones en materia de responsabilidad deontológica para el ejercicio de la profesión de Enfermería en Colombia; se establece el régimen disciplinario correspondiente y se dictan otras disposiciones. Bogotá: Diario Oficial $45693 ; 2004$.

5. Torres-Contreras C, Buitrago-Vera M. Percepción de la calidad del cuidado de enfermería en pacientes oncológicos hospitalizados. Cuidarte 2011; 2(1): 138-148.

6. Puga-García A, Madiedo-Albolatrach M, Brito-Hernández I. Filosofía y ciencia de la enfermería vinculada al proceso formativo de sus recursos humanos. Rev. Gaceta Médica Espirituana. 2007; 9(2).

7. Ramalho-Neto JM, Antão-Marques DK, Melo-Fernandes MG, Lima-Nóbrega- MM. Análise de teorias de enfermagem de Meleis: revisão integrativa. Rev. Bras. Enferm. 2016; 69(1):174-181.

8. Marriner A, Raile M. Modelos y teorías en enfermería. $7^{\mathrm{a}}$ ed. España: Elsevier; 2011.

9. Delgado T, Bentancur L. Dificultad en la enseñanza del proceso enfermero en una universidad privada de la ciudad de Montevideo. Enfermería (Montev.) 2012; 1(2): 103-111.

10. Gallardo AI. Evolución del conocimiento de Enfermería. Medwave 2011; 11(04): e5001.

11. Aguilar-Serrano L, López-Valdez M, Bernal-Becerril ML, Ponce-Gómez G, Rivas-Espinosa JG. Nivel de conocimientos acerca del proceso enfermero y la percepción de autoeficacia para su aplicación. Rev Enferm Inst Mex Seguro Soc 2008; 16(1): 3-6.

12. Huitzi-Egilegor J, Elorza-Puyadena MI, Urkia-Etxabe JM, Maria Esnaola-Herrero MV, Asurabarrena-Iraola C. Estudio retrospectivo de la implantación del proceso de enfermería en un área de salud. Rev. Latino-Am. Enfermagem 2013; 21(5).

13. Guerra-Cabrera E, Pozo-Madera E, Álvarez-Miranda L, Llanoazo M. El proceso de atención de enfermería y la formación de los profesionales. Rev. Cubana Educ Med Super 2001; 15(1): 30-8.

14. Cogollo-Jiménez R. Una mirada al cuidado de la familia con adolescente. Rev. cienc. cuidad. $2013 ; 10(2)$ : $58-64$.

15. Gutiérrez-Lesmes $O$. Factores que determinan la aplicación del proceso de enfermería en Instituciones hospitalarias de Villavicencio, Colombia, 2008. av. enferm. 2009; 27(1): 60-68.

16. Durán-Villalobos MM. La teoría, soporte de la ciencia y práctica de enfermería: tendencias. av. enferm. 2012; 30(1): 9-12.

17. Tiga-Loza DC, Parra DI, Domínguez-Nariño CC. Competencias en proceso de enfermería en estudiantes de práctica clínica. Cuidarte 2014; 5(1): 585-594.

18. Álvarez-Rodríguez T, Fernández-Lamelas, MA, Álvarez-Aragón F, López-Vale C, Lago-Lemos A. Asumiendo competencias desde la aplicación NANDA, NIC, NOC en la práctica clínica. Enferm. glob. 2007; 10(11): 1-7.

19. Serrano-Lázaro R. Competencias de aprendizaje detectado en los casos clínicos realizados por los estudiantes de enfermería bajo los criterios NANDA NIC NOC en las unidades de M. I. y Psiquiatría. [Tesis]. España: Universidad de Zaragoza; 2012.

20. Navarro-Peña Y, Castro-Salas M. Modelo de Dorotea Orem aplicado a un grupo comunitario a través del proceso de enfermería. Enferm. glob. 2010; 19: 1-14.

21. López-Díaz AL, Guerrero-Gamboa S. Perspectiva Internacional del uso de la teoría general de Orem. Invest. educ. enferm 2006; XXIV(2): 90-100.

22. Rodríguez-Martínez R. Modelos de enfermería integrados al cuidado del paciente nefrológico en el contexto cubano. Rev Cubana Enfermer 2012; 28(4): 474-484.

23. Prado-Solar LA, González-Requena M, Paz-Gómez N, Romero-Borges K. La teoría Déficit de auto cuidado: Dorothea Orem punto de partida para calidad en la atención. Rev. Med. Electron 2014; 36(6): 835-845.

24. Moreno-Fergusson ME, Alvarado-García AM. Aplicación del Modelo de Adaptación de Callista Roy en Latinoamérica. Aquichan 2009; 9(1): 62-72.

25. Trejos-Martínez F. Aplicación del modelo de Nola Pender a un adolescente con sedentarismo. Enf Neurol (Mex) 2010; 9 (1): 39-44.

26. Pino-Armijo P. Aplicación de la teoría de Henderson y su aproximación al cuidado avanzado en enfermería en 
un servicio de pediatría. Medwave 2012; 12(10): e5548.

27. Bernárdes-Carballo K, Sánchez-Hernández DL, Hernández-Amaran L, Arcia-Conil RC. Aplicación de la teoría de Florence Nigtíngale a un anciano con asma bronquial. Rev Ciencias Médicas 2012; 16 (4):3-12.

28. Backes DS, Grando MK, Araújo-Gracioli MS, Dall'asta-Pereira A, Colomé JS, Gehlen MH. Vivência teóricoprática inovadora no ensino de enfermagem. Esc. Anna Nery 2012; 16(3): 597-602.

29. Moreno-Fergusson ME. Importancia de los modelos conceptuales y teorías de enfermería: Experiencia de la Facultad de Enfermería de la Universidad de la Sabana. Aquichán 2005; 5(1): 44-55.

30. Rodrigues-Barbosa de Sousa JE, Freitas-Da Silva, Barros-Aráujo MH, Lima-Pereira ML. Concepciones teóricas de Neuman asociadas con la prevención de las úlceras por presión: Un estudio de caso. Index Enferm 2015; 24(4): 222-226.

31. Ledesma-Delgado ME, Rino-Mendes MM. El proceso de enfermería como acciones de cuidado rutinarias: construyendo su significado en la perspectiva de las enfermeras asistenciales. Rev. Latino-Am. Enfermagem 2009; 17(3): 328-334.

32. Rojas JG, Pastor-Durango P. Aplicación del proceso de atención de Enfermería en cuidados intensivos. Investigación y Educación en Enfermería 2010; 28 (3): 323-335.

33. Duque PA. Factores relacionados con la aplicabilidad del Proceso de Atención de Enfermería en una institución de salud de alta complejidad en la ciudad de Medellín. Rev. Univ. salud 2014; 16(1): 91-102.

34. Correa-Valenzuela SE, García-Campos ML. Proceso enfermero a recién nacido con hiperbilirrubinemia basado en el modelo de adaptación de Roy. Enfermería Universitaria. 2015; 12(4): 226-234.

35. García-Rueda A, Ibáñez-Alfonso LE. Sistematización de una experiencia de cuidado con los y las adolescentes. Rev. cienc. cuidad. 2013; 10(2): 65-75.

36. República de Colombia, Ministerio de Protección Social. Ley 1438 de 2011, enero 19, por medio de la cual se reforma el Sistema General de Seguridad Social en Salud y se dictan otras disposiciones. Bogotá D.C.: El Ministerio / Diario Oficial 47957; 2011.

37. Tirado-Pedregosa G, Hueso-Montoro C, Cuevas-Fernández M, Montoya-Juárez R, Bonill-Nieves C, SchmidtRío-Del Valle J. Cómo escribir un caso clínico en Enfermería utilizando Taxonomía NANDA, NOC, NIC. Index Enferm 2011; 20(1-2): 111-115.

38. Navarrete-Cortés L, Santiago-García S. Aplicación de un Plan de Cuidados Enfermeros utilizando el modelo de Virginia Henderson (catorce necesidades) a una persona que presenta lesiones causadas por pénfigo vulgar. Caso clínico. Enf Neurol (Mex) 2014; 13 (1): 37-42.

39. Cobos-Serrano JL. Impacto, de la implementación de una metodología normalizada y un sistema de registro de información de cuidados de enfermería, en la calidad asistencial. Reduca 2009; 1(2): 895-912.

40. Oreja-Vázquez ML, Alegre-Vega C. Interrelaciones NANDA, NOC, NIC. Metodología Enfermera. A propósito de un caso. Norte de Salud Mental 2008; 7(31): 20-26.

41. Escaño-Cardona V, Rebola-González P. Taxonomía diagnóstica NANDA, NOC, NIC en paciente con Colangitis Aguda que sufre Pancreatitis tras CPRE. Rev. Enfermería Docente 2013; 99: 20-25.

42. Bros-Serra M. Aplicación de los lenguajes estandarizados NANDA, NOC y NIC en la asignatura de Enfermería Geriátrica. Gerokomos. 2006; 17(3): 140-143.

43. González-Sara SH, Moreno-Pérez NE. Instrumentos para la enseñanza del proceso enfermero en la práctica clínica docente con enfoque de autocuidado utilizando Nanda-Nic-Noc. Enferm. glob. 2011; 10(3): 89-95.

44. García-Rangel K, Rivas-Espinosa JG. Relación de etiquetas NANDA e indicadores NOC, respecto al porcentaje de sobrevida en pacientes politraumatizados. Rev CONAMED 2010; 15 (Suppl 1): 4-10.

45. Rivas-Espinosa JG, Álvarez-Sanvicente ME, Cruz-Santiago C, Martínez-Salamanca FJ, Aguilera-Rivera M, Ibáñez-Chávez DR. Etiquetas diagnósticas en pacientes hospitalizadas con diagnóstico de cáncer cérvicouterino. Rev. CONAMED. 2008; 13 (Suppl 2): 23-29.

46. Pinilla-Gómez E, Pérez-Sierra JM. Prevalencia de diagnósticos de enfermería en escolares desplazados víctimas de la violencia social e intrafamiliar. Rev. Univ. Ind. Santander. Salud 2009; 41 (2): 149-156.

47. Aguilera-Rivera M, Martínez-Salamanca FJ, Rivas-Espinosa JG. Propuesta metodológica de una guía clínica del cuidado: tratamiento hemodialítico. Rev. CONAMED. 2008; 13 (Suppl 2): 6-14.

48. Hein-Seganfredo D, De Abreu-Almeida M. Validación de contenido de resultados de enfermería según la clasificación de los resultados de enfermería NOC para pacientes clínicos, quirúrgicos y críticos. Rev. LatinoAm. Enfermagem 2011; 19(1).

49. Borré-Ortiz YM, Lenis-Victoria C, Suárez-Villa M, Tafur-Castillo J. El conocimiento disciplinar en el currículo de enfermería: una necesidad vital para transformar la práctica. Rev. Cienc. Salud. 2015; 13(3): 481-491.

50. Sancho-Cantus D, Prieto-Contreras L. Teorías y modelos en la práctica enfermera: ¿Un binomio imposible? Enferm. glob. 2012; 11(27): 292-298. 